\title{
Evaluation of communication training programs in nursing care: a review of the literature
}

\author{
Irma P.M. Kruijver MSc ${ }^{\mathrm{a}, *}$, Ada Kerkstra $\mathrm{PhD}^{\mathrm{b}}$, Anneke L. Francke $\mathrm{PhD}^{\mathrm{b}}$, \\ Jozien M. Bensing $\mathrm{PhD}^{\mathrm{a}, \mathrm{c}}$, Harry B.M. van de Wiel $\mathrm{PhD}^{\mathrm{d}}$ \\ ${ }^{a}$ NIVEL, Netherlands Institute of Primary Health Care, Utrecht, The Netherlands \\ ${ }^{\mathrm{b}}$ Department of Nursing and Caring Research, Netherlands Institute of Primary Health Care, Utrecht, The Netherlands \\ ${ }^{\mathrm{c} D e p a r t m e n t}$ of Clinical and Health Psychology, University of Utrecht, Utrecht, The Netherlands \\ ${ }^{\mathrm{d}}$ Academic Hospital Groningen, Department of Medical Psychology, Groningen, The Netherlands
}

Received 27 November 1998; received in revised form 5 August 1999; accepted 6 September 1999

\begin{abstract}
An important aspect of nursing care is communication with patients. Nurses' major communication tasks are not only to inform the patient about his/her disease and treatment, but also to create a therapeutically effective relationship by assessing patients' concerns, showing understanding, empathy, and providing comfort and support. In this review, 14 studies, which focus on the evaluation of the effects of communication training programs for nurses, have been evaluated. The selected studies were screened on several independent, process and outcome variables as described by Francke et al. [8]. In this way not only is the training program taken into account as a variable which may be responsible for nurses' behavioural change and for changes in patient outcomes, but also a range of other variables which can give more nuanced explanations for a training program's degree of effectiveness. On the whole, the studies reviewed showed limited or no effects on nurses' skills, on nurses' behavioural changes in practice, and on patient outcomes. Finally, the majority of the studies had a weak design. The use of experimental research designs should be pursued in future studies in order to eliminate the influence of confounding variables. (C) 2000 Elsevier Science Ireland Ltd. All rights reserved.
\end{abstract}

Keywords: Nurses; Communication training programs, Evaluation

\section{Introduction}

Within current nursing care, increasing attention is being paid to effective communication, which ac-

\footnotetext{
*Corresponding author. Tel.: + 31-30-272-9700; fax: + 31-30272-9279.

E-mail address: i.kruyver@NIVEL.nl (I.P.M. Kruijver)
}

cording to Wilkinson [1,2] is defined as open twoway communication in which patients are informed about the nature of their disease and treatment and are encouraged to express their anxieties and emotions. Two communicative behaviours employed by nurses seem to be important in meeting the communication needs of patients as defined above. First are the instrumental behaviours, which are of signifi- 
cance in informing the patient about the disease and treatment. Second are affective behaviours, such as showing respect and providing comfort and trust [3] which are important in creating a good relationship with the patient. An additional distinction to be made is that between the verbal and nonverbal components of communication within instrumental and affective communication. Nonverbal communication refers to paralinguistic features and behaviour, which conveys messages without the use of verbal language. Examples are speech rate, speech volume, facial expression, eye contact, posture, gesture, physical appearance and touch. Nonverbal communication appears to be especially important with respect to building rapport with others, and for conveying empathy and support [4,5].

In the case of life-threatening diseases such as cancer, in particular, nurses report a need for communication training programs in which they can learn how to communicate effectively on emotional issues and psychosocial aspects, and also how to integrate these issues purposefully in delivering medical or technical care in nursing practice $[6,7]$.

During the last decade, many training programs in communication have been developed which target the improvement of nurses' communicative behaviours in daily practice. However, the literature reveals that relatively few of these programs have been evaluated. Evaluation studies are useful in gaining insight into the effect of these programs on nurses' levels of communication skill and other nurse and patient outcomes.

The effectiveness of communication training programs is not only dependent on program characteristics, but may be affected by a range of other variables as well. On the basis of a review of the literature, Francke et al. [8] described several independent and process variables, which may be related to behavioural changes in nurses following training programs.

In the first place, nurses' working experience is an independent variable. It is a background characteristic. The fact that inexperienced participants who have only a few years of nursing experience, may profit more from training programs than experienced nurses $[9,10]$ illustrates its influence. Other independent variables further include characteristics of the program itself (e.g., topics and duration), and the professional background of the teachers. Finally, independent variables include the social system in the working environment. Characteristics of the social system in the working environment include social support from superiors, and encouragement from colleagues in applying the newly acquired knowledge and skills in daily practice.

Process variables include the characteristics of the relationship with the teacher and that among the participants. Nurses often prefer warm, enthusiastic, friendly teachers with a great deal of expertise. Reciprocal sympathy and support, respect and feedback among participants may also contribute to the success of the learning process [8].

Francke et al. [8] also described several outcome variables, which may be important mediators for behavioural change in practice. These include knowledge, skills, attitudes and an intention to change behaviours after the training. These variables mediate nurses' behavioural changes. However, the literature reveals $[11,12]$ that positive changes in knowledge, skills, attitudes and the intention to change do not automatically lead to actual behavioural changes. Yet, we consider behavioural changes highly important, since they are, in turn, (partially) responsible for positive changes in patient outcomes.

We screened selected studies of the independent process and outcome variables mentioned in this review of the literature. This allowed us not only to take the training program into account as a variable, possibly responsible for nurses' behavioural change and changes in patient outcomes, but also for a range of other variables. It may be helpful in explaining the effects of a communication training program. In addition, we looked at the research methods used in the selected evaluation studies to interpret the value of the effects measured.

The research questions addressed in this article are:

1. What are the characteristics of the communication training programs evaluated for nurses with regard to the following independent variables: participants' background characteristics, professional background of the teachers, characteristics of the training program?

2. What research methods are used to evaluate the outcomes of the training? 
3. What are the process-oriented and effect-oriented outcomes of the training programs?

\section{Methods}

In order to obtain the relevant literature, a search was made of three data bases, running from 1985 to 1998: Medline, Nursing and Allied Health Literature and the Catalogue of the Netherlands Institute of Primary Health Care. The bibliographies of the selected articles also revealed some relevant articles, running from 1979. In general, studies of communication training programs for nurses appeared to be scarce. For this reason, the literature search covers the long period from 1979 through 1998. The majority of the articles selected, however, were from the last ten years.

The key words used in these searches were: nurse-patient relations/interaction in combination and sequence with: communication skills; training; teaching; education programs.

A total of 53 references were found by these searches. The following inclusion criteria were used for the review:

- The study was directed at evaluating communication training for nurses only or for nurses in combination with other professionals.

- It was published in English or Dutch.

- It was published as a thesis or in a scientific journal.

Considering the small number of evaluation studies found, all the studies which met these criteria were included, regardless of the quality of the training program or the evaluation methods used. Fourteen studies met the inclusion criteria, and are described in the Results section.

\section{Results}

\subsection{Independent variables}

The studies, when compared on the independent variables, showed the following results (see Table 1).

\subsubsection{Characteristics of the participants}

\subsubsection{Setting}

Participants were working in an oncology setting (in eight studies), in a psychiatric setting (in one study); in a psychogeriatric setting (in one study), or in a general health care setting (in four studies).

\subsubsection{Discipline(s)}

Table 1 shows that in twelve studies, the participants were nurses. In four studies, the group was multi-disciplinary, also including physicians [13,14], social workers [13,15], psychologists [13], nursing and medical students and dieticians [16]. The number of participants ranged from 8 to 218 .

\subsubsection{Working experience}

The studies of Pool [10] and Grond and Visser [9] showed that nurses' working experience can change the effects of the training. Both studies showed that participants with little nursing experience reported most behavioural changes. The study by Ravazi et al. [18] which took place in an oncology setting was the only study which documented at least six months participant experience in caring for cancer patients. In five studies, registered nurses participated; registered nurses and student nurses participated in four studies. One study [17] had only student nurse participants. In the study by Booth et al. [19] and Grond and Visser [9], it was reported that all ward staff participated (including experienced and inexperienced patients).

Finally, in two studies, the nurses' working experience was not documented.

\subsubsection{Characteristics of the training program}

\subsubsection{Topics}

The training programs selected focused on teaching various types of communication skills, (see Table 1). The different skills were taught to improve interaction between nurses and patients. Facilitating skills were taught in order to encourage patients to disclose their concerns particularly in the training programs in oncology. In the studies by Ravazi et al. 
Table 1

Independent and process variables related to behavioural change following communication training

\begin{tabular}{|c|c|c|c|c|c|}
\hline \multirow[t]{2}{*}{ Authors } & \multicolumn{4}{|l|}{ Independent variables } & \multirow{2}{*}{$\begin{array}{l}\text { Process variables } \\
\text { Characteristics of relationships } \\
\text { with teachers and participants }\end{array}$} \\
\hline & Characteristics of the participants & Training: didactic strategies, duration, topics & $\begin{array}{l}\text { Social system } \\
\text { of the working environment }\end{array}$ & $\begin{array}{l}\text { Background } \\
\text { teachers }\end{array}$ & \\
\hline $\begin{array}{l}\text { Grond and } \\
\text { Visser [9] }\end{array}$ & $\begin{array}{l}\text { Setting/discipline: general } \\
\text { health care/two surgical } \\
\text { wards of a general hospital } \\
\text { in the Netherlands } \\
\text { Experience: not explicitly } \\
\text { documented } \\
\text { (All nursing staff) }\end{array}$ & $\begin{array}{l}\text { Didactic strategies: } \\
\text { theoretical part: studying and discussing theory; } \\
\text { practical part: role-playing exercises and discussion } \\
\text { Duration: } 4 \times 1.5 \mathrm{~h} \\
\text { Topics: therapeutic behaviours, especially the nondirective } \\
\text { skills (warmth, empathy) }\end{array}$ & - & $\begin{array}{l}\text { Psychology } \\
\text { (one trainer) }\end{array}$ & - \\
\hline Pool [10] & $\begin{array}{l}\text { Setting/discipline: general } \\
\text { health care/nurses working } \\
\text { on different wards of a } \\
\text { general hospital. } \\
\text { Experience: Registered aswell } \\
\text { as learner nurses }\end{array}$ & $\begin{array}{l}\text { Didactic strategies: } \\
\text { theoretical part: studying and discussing theory } \\
\text { practical part: role-playing exercises and discussion } \\
\text { Duration: } 8 \times 2.5 \mathrm{~h} \\
\text { Topics: therapeutic behaviours, especially the non directive } \\
\text { skills }\end{array}$ & $\begin{array}{l}\text { A barrier } \\
\text { bringing into } \\
\text { practice the } \\
\text { therapeutic skills } \\
\text { learned during } \\
\text { the training as a } \\
\text { consequence of } \\
\text { time pressure } \\
\text { and a negative } \\
\text { attitude of } \\
\text { colleagues. }\end{array}$ & $\begin{array}{l}\text { Social } \\
\text { psychology } \\
\text { (two trainers) }\end{array}$ & $\begin{array}{l}\text { The teachers were unfamiliar with } \\
\text { nursing practice; they had a } \\
\text { general approach }\end{array}$ \\
\hline $\begin{array}{l}\text { Maguire } \\
\text { et al. [13] }\end{array}$ & $\begin{array}{l}\text { Setting/discipline: } \\
\text { oncology/health } \\
\text { professionals: } 65 \% \text { nurses. } \\
\text { Experience:?? }\end{array}$ & $\begin{array}{l}\text { Didactic strategies: theoretical part: videotape demonstration } \\
\text { of key communication skills, and discussion; a practical part: } \\
\text { role-playing sessions } \\
\text { Duration: } 3 \text { or } 5 \text { days } \\
\text { Topics: interviewing skills }\end{array}$ & - & $\begin{array}{l}\text { Background } \\
\text { and number } \\
\text { of trainers: ?? }\end{array}$ & - \\
\hline $\begin{array}{l}\text { Ravazi et al. } \\
\text { [14] }\end{array}$ & $\begin{array}{l}\text { Setting/dicipline: } \\
\text { oncology/health } \\
\text { professionals working in } \\
\text { different cancer centres. } \\
\text { Experience: licensed health } \\
\text { professionals }\end{array}$ & $\begin{array}{l}\text { Didactic strategies: exchange of experiences, theoretical } \\
\text { information, role-playing sessions, case discussions } \\
\text { Duration: } 12 \text { h (weekly sessions of } 180,120,90 \text { or } 75 \\
\text { min). } \\
\text { Topics: attitude towards death and dying }\end{array}$ & - & $\begin{array}{l}\text { Psychology/ } \\
\text { psychiatry } \\
\text { (two trainers) }\end{array}$ & - \\
\hline $\begin{array}{l}\text { Faulkner } \\
{[15]}\end{array}$ & $\begin{array}{l}\text { Setting/dicipline: } \\
\text { oncology/health } \\
\text { professionals caring for } \\
\text { cancer patients (hospice } \\
\text { doctors, Macmillan nurses, } \\
\text { social workers, and other } \\
\text { health care providers) } \\
\text { Experience: licensed health } \\
\text { professionals }\end{array}$ & $\begin{array}{l}\text { Didactic strategies:?? } \\
\text { Duration:?? } \\
\text { Topics: assessment skills and psychological depth }\end{array}$ & - & $\begin{array}{l}\text { Background } \\
\text { and number } \\
\text { of trainers: ?? } \\
\text { (not clearly } \\
\text { documented) }\end{array}$ & - \\
\hline
\end{tabular}




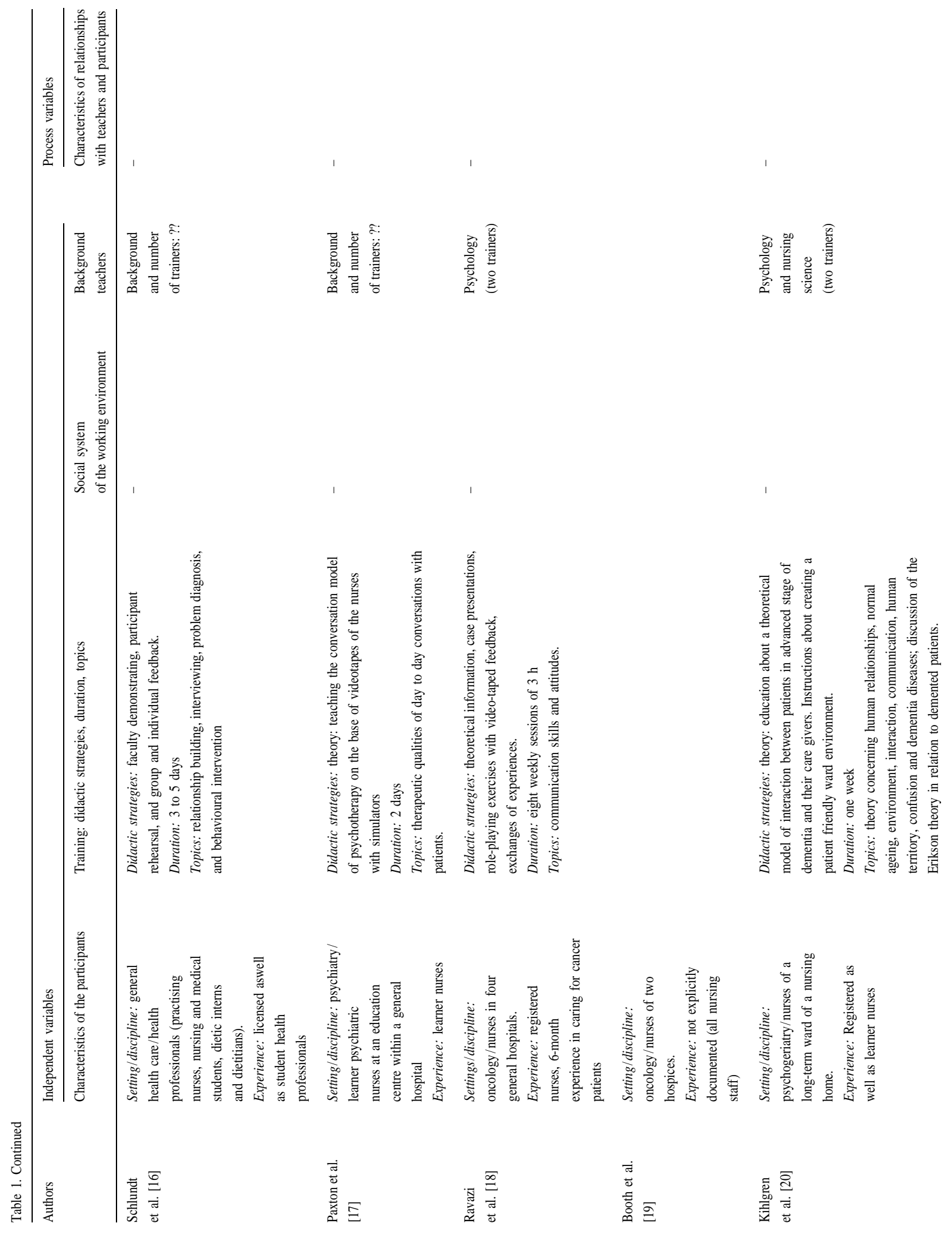




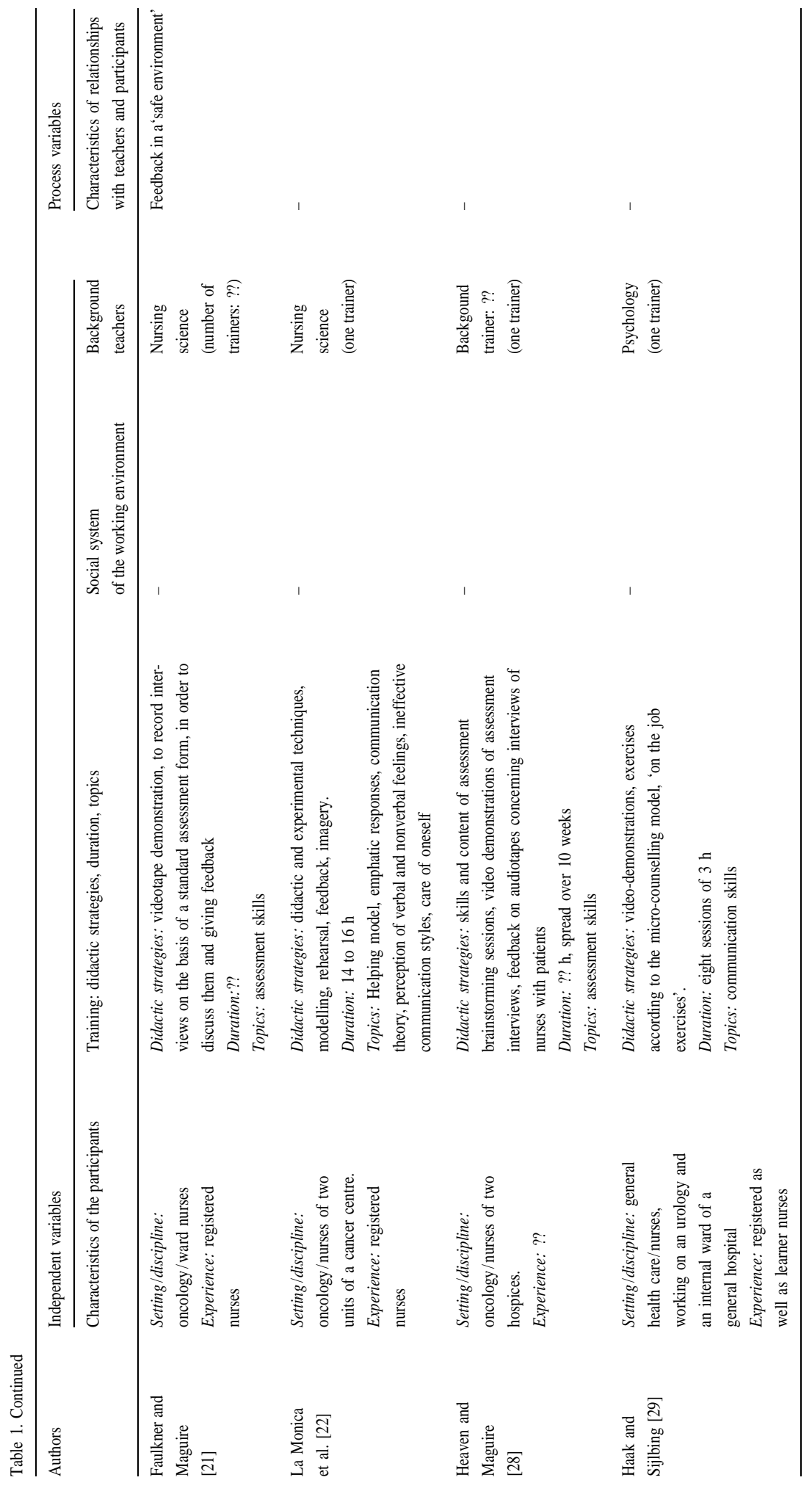


[14,18], a training program was evaluated which aimed not only at improving nurses' communication skills, but also at positively changing nurses' attitudes towards their work, and decreasing nurses' stress.

In one study, nurses were trained in communication skills to promote patient compliance [16]; finally, in the study by Kihlgren et al. [20] nurses were not only taught skills, but also taught how to create a patient friendly environment to optimize psychosocial treatment for psychogeriatric patients.

\subsubsection{Didactic strategies}

In the selected studies, theoretical and/or practical didactic strategies were presented (see Table 1). The theoretical strategies included techniques such as theoretical information, discussion of the theory and cases, exchange of experience and information, and modelling. The practical instructions included roleplaying exercises, rehearsal, feedback and 'on the job' exercises.

In nine studies, the program included a combination of practical as well as theoretical training. Roleplaying and feedback were often used as didactic strategies within the selected studies.

Two studies [17,20], gave theoretical training only; one study taught only practical skills [21]. Finally $[13,22]$, there were two studies without didactic strategies.

\subsubsection{Duration}

All but two of the studies [15,21] provided information about the duration of training (see Table 1). In eight studies, this information was provided in terms of hours, and in six studies in terms of the time period in which sessions took place. The number of hours ranged from six to 24; the training periods ranged from two days to ten weeks.

\subsubsection{Professional background trainers}

In two studies, the trainer(s) had a nursing background; in four a psychology background; in two studies the trainers had professional backgrounds in two disciplines: both in nursing as well as psychology [20], or psychology and psychiatry [14]. In six studies, the trainer's background was not documented. One study [10] gave some information about the relationship between background of the trainer and nurse/patient outcomes. Pool [10] reported that, in nurses' opinion, teachers were unfamiliar with nursing practice and that their approach was too general. Pool suggested that this had a negative influence on nurses' behaviour change in practice.

\subsubsection{The social system of the working environ- ment}

Two studies mentioned the influence of nurses' working environment on the use of skills in practice. Booth et al. [19] found that nurses used blocking behaviours less frequently when they received practical and emotional support from their supervisors. Pool [10] reported that nurses were hindered in putting the therapeutic skills learned during training into practice as a consequence of time pressure and negative attitudes on the part of colleagues.

\subsection{Research design and instruments used to evaluate the training outcomes}

\subsubsection{Research design}

Three studies had a classic experimental research design, individual participants were randomly allocated to a control and an experimental ward (see Table 2). In another study [22] randomization took place at ward level, which meant that the wards were randomly allocated as a control or experimental ward. A pretest-post-test nonrandomized design with an experimental and a control group was used in four studies. A single group pretest-post-test design was used in six studies.

On the whole, the pre-tests were often a few days before training; the post-tests varied from a few days to three months after training.

In five studies, two post-tests were used. The second post-test varied from two to nine months after the first post-test.

\subsubsection{Instruments: type}

\subsubsection{Measuring nurses' communication skills}

In order to assess communication skills, videotapes (in four studies) or audiotapes (in seven studies) were made of interviews between nurses and 


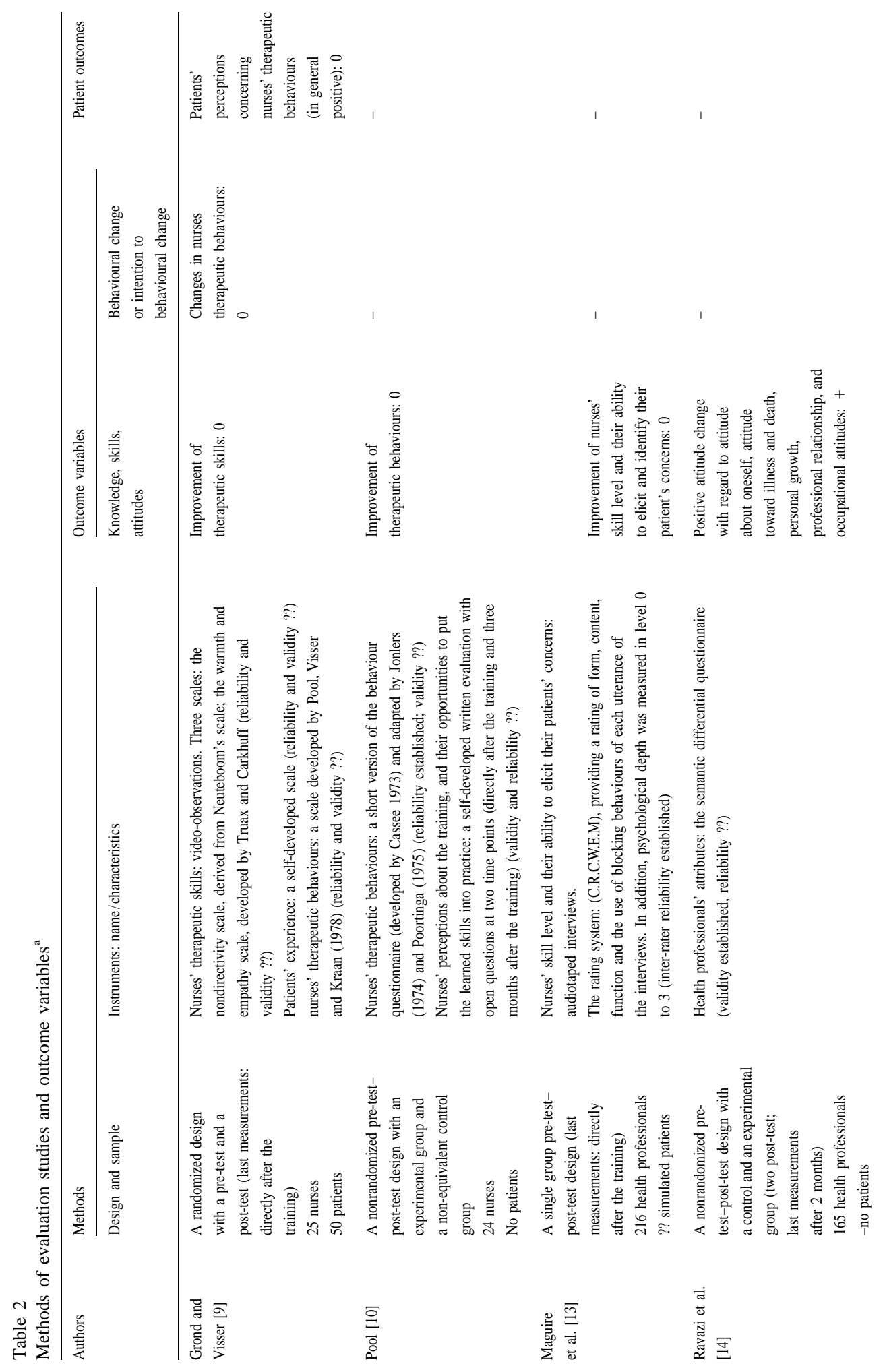


I.P.M. Kruijver et al. / Patient Education and Counseling 39 (2000) 129-145

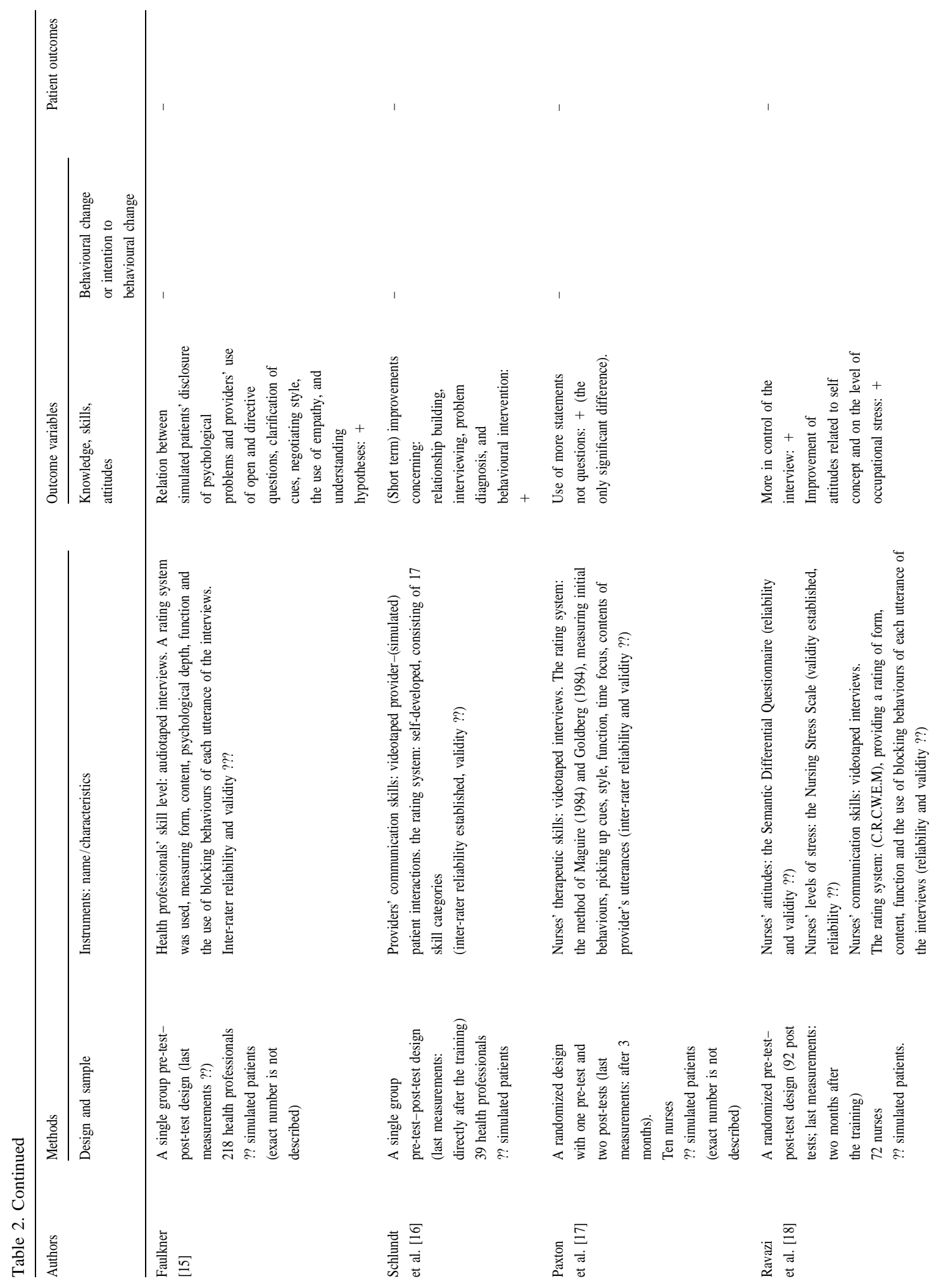




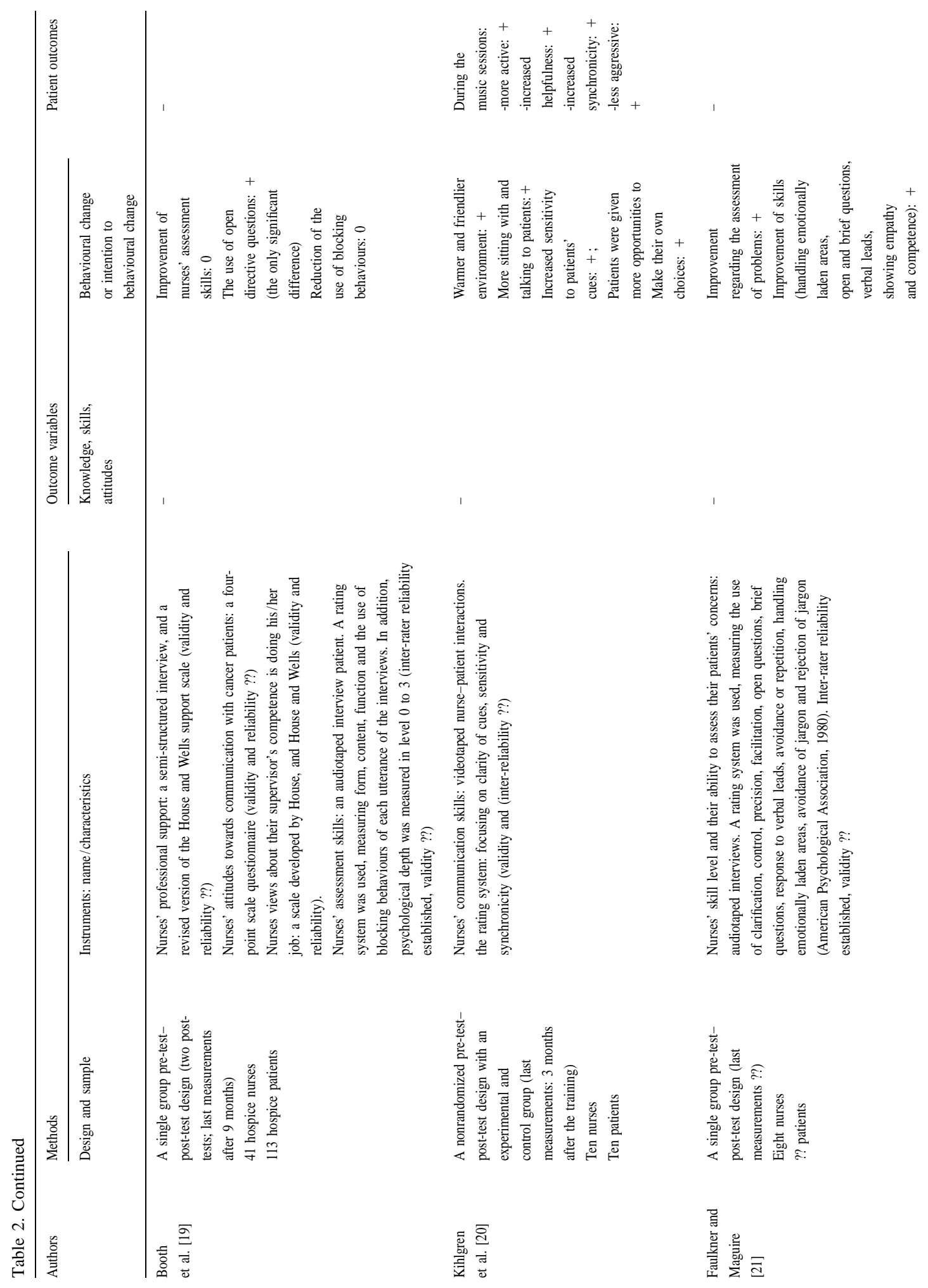


Table 2. Continued

\begin{tabular}{|c|c|c|c|c|c|}
\hline \multirow[t]{2}{*}{ Authors } & \multicolumn{2}{|l|}{ Methods } & \multicolumn{2}{|l|}{ Outcome variables } & \multirow[t]{2}{*}{ Patient outcomes } \\
\hline & Design and sample & Instruments: name/characteristics & $\begin{array}{l}\text { Knowledge, skills, } \\
\text { attitudes }\end{array}$ & $\begin{array}{l}\text { Behavioural change } \\
\text { or intention to } \\
\text { behavioural change }\end{array}$ & \\
\hline $\begin{array}{l}\text { La Monica } \\
\text { et al. [22] }\end{array}$ & $\begin{array}{l}\text { A randomized pre- } \\
\text { post-test (last measurements: } \\
\text { directly after the } \\
\text { training) } \\
109 \text { nurses } \\
656 \text { patients }\end{array}$ & $\begin{array}{l}\text { Patient outcome measures: the Multiple Affect Adjective Check List } \\
\text { and the La Monica/Oberst Patient Satisfaction Scale (validity and } \\
\text { reliability established); } \\
\text { Nurse outcome measures: the Empathy Construct Rating Scale } \\
\text { (validity and reliability established) }\end{array}$ & $\begin{array}{l}\text { Improvement of empathy } \\
\text { skills (self report ECRS } \\
\text { as well as patient rating) } \\
\text { scores: } 0\end{array}$ & & $\begin{array}{l}\text { Less anxiety } \\
\text { and hostility: }+\end{array}$ \\
\hline $\begin{array}{l}\text { Heaven and } \\
\text { Maguire } \\
{[28]}\end{array}$ & $\begin{array}{l}\text { A single group pre- } \\
\text { post-test design }(92 \\
\text { post-tests; last measurements: } \\
\text { after } 9 \\
\text { months) } \\
44 \text { nurses } \\
87 \text { cancer patients }\end{array}$ & $\begin{array}{l}\text { Nurses' assessment skills: audiotaped interviews. A rating system was } \\
\text { used, measuring psychological depth, form, function blocking behaviors } \\
\text { and behaviours which show concern of nurses (validity and } \\
\text { (inter)reliability ??) } \\
\text { Patients' state of anxiety and depression: the Hospital Anxiety and } \\
\text { Depression Scale (HADS) and the Spielberger State Anxiety questionnaires } \\
\text { (SSA) (validity and reliability ??) }\end{array}$ & - & $\begin{array}{l}\text { Improvement of nurses' } \\
\text { skill level and } \\
\text { their ability to elicite } \\
\text { and identify their patient's } \\
\text { concerns: } 0\end{array}$ & Not reported \\
\hline $\begin{array}{l}\text { Haak and } \\
\text { Sijlbing } \\
{[29]}\end{array}$ & $\begin{array}{l}\text { A nonrandomized pre- } \\
\text { post-test design with a } \\
\text { control and an experimental } \\
\text { group (last } \\
\text { measurements: directly } \\
\text { after the training) } \\
20 \text { nurses } \\
81 \text { simulated patients }\end{array}$ & $\begin{array}{l}\text { Nurses' communication skills: videotaped observations. The rating } \\
\text { system: eight observation categories (not clear documented) (inter- } \\
\text { rater-reliability established, validity ??). } \\
\text { Patients' perceptions of nurses change in communication skills: the } \\
\text { 'gespreksvaardigheden vragenlijst' (GV) (reliability established, validity } \\
\text { ??) }\end{array}$ & $\begin{array}{l}\text { Improvement of } \\
\text { communication skills: } 0\end{array}$ & $\begin{array}{l}- \\
-\end{array}$ & $\begin{array}{l}\text { Patients' } \\
\text { perceptions about } \\
\text { changes of } \\
\text { nurses' } \\
\text { communication } \\
\text { skills: } 0\end{array}$ \\
\hline
\end{tabular}

${ }^{\text {a }}$ Explanation of the signs: $+=$ positive effects; $0=$ no positive effects. 
patients (see Table 2). In five studies, interviews were taped with simulated patients; in six studies real patients were involved in the taped interviews with nurses.

With the exception of the study by Grond and Visser [9], nurses' skills were observed during the interviews, using an observation system tailored to the specific skills taught during training. In the study by Grond and Visser [9], nurses' therapeutic skills were observed using three generic scales: the nondirectivity scale derived from Neuteboom [23], and warmth and empathy scale, developed by Truax and Carkhuff [24].

With regard to the majority of the studies in the oncology setting, the observation systems used the same categories, but small adaptations were made for the different oncology studies. This makes the different studies comparable (see Table 2).

In addition to observations on tape which is a direct observational method, nurses' self-reporting in the form of questionnaires, was used to measure skill levels. La Monica et al. used the Empathy Construct Rating scale to measure empathy skills. In the study by Pool and Grond and Visser, the short version of the therapeutic behaviour questionnaire developed by Cassee [25] and adapted by Jonkers [26] and Poortinga [27] was used to measure therapeutic behaviours.

\subsubsection{Measuring other nurse outcomes}

The studies by Ravazi et al. [14,18] are the only studies in which communication skills were taught but not explicitly measured as an outcome variable. Ravazi et al. measured the impact of the training on nurses' attitudes towards their work, using the Semantic Differential Questionnaire [14,18], and the impact of the training on nurses' stress levels, using the Nursing Stress Scale [18].

\subsubsection{Measuring patient outcomes}

In three studies, questionnaires were used to measure patient outcomes, such as state of depression and anxiety [22,28], satisfaction with care [22], perception of the quality of communication with the nurses [9] or perceptions of change in nurses' communication skills after the training [29].

\subsubsection{Validity and reliability of the instruments}

3.2.3.1. Instruments measuring nurses' skills: coding systems and questionnaires

In three studies the inter-rater reliability of the coding system is explicitly documented. Correlations varied from 0.68 [29] to 0.87 [16], the significance of the agreements measured with kappa coefficient varied from $p<0.05$ to $p<0.01$ [21]. In the study by Maguire et al. [13], and Heaven and Maguire [28] it was stated that there was an acceptable agreement, but it was not explicitly documented. The validity of the coding systems was not documented in any study.

In three studies [9,10,22], a questionnaire was used to measure nurses' skills. Evidence for reliability and validity of the scale, used in the study by la Monica et al. was not presented in this study but in another one. Only in the study by Pool [10], was the reliability of the scale documented; Chronbachs alpha varied from 0.85 and 0.89 . The validity of this scale is not reported.

\subsubsection{Instruments measuring other nurse out-} comes, and patient outcomes

Only those instruments used in the studies by Ravazi et al. [14,18], in order to measure nurses' stress and attitudes have proved reliable (stress) or valid (attitudes).

With regard to the patient outcomes, the instruments used in the study by La Monica et al. [19] in order to measure patient satisfaction and depression have proved reliable and valid in the literature. No detailed information about them is given in $\mathrm{La}$ Monica's study. Finally, reliability of the scale used in the study by Haak and Sijlbing [29] was established; in this, patients perceptions of the quality of nurses communication skills were measured.

\subsection{Process and outcome variables}

In addition to the independent variables, we screened the studies of our review for process and mediating outcome variables, as defined by Francke et al. [8], as well as on outcomes relating to nurses' behavioural changes in daily practice, and patient outcomes. 
3.3.1. Characteristics of the trainer, their relationship with the participants, and the relationship between participants

One study [21] reported the importance of giving the participants feedback on their performance in a 'safe environment'. This included first giving the participants feedback about their good points to reduce the risks of undermining confidence (see Table 1).

\subsubsection{Skills, attitudes and knowledge}

The influence of the training on nurses' attitudes, skills and knowledge was measured in studies in which video or audio observations were made of nurses interaction with simulated patients $[13,15,16-$ $18,29]$, and/or in studies in which questionnaires [9,14,22] were used (see Table 2).

Ravazi et al. reported a positive change in nurses attitudes, especially attitudes toward illness and death, personal growth professional relationship [18] and occupational stress related to inadequate preparation [14].

Paxton et al. [17] found a significant change in one style of behaviour: after training, nurses used statements more as opposed to questions. Faulkner [15] reported a significant relation between simulated patients' disclosure of psychological problems and providers' use of open and directive questions, clarification of cues, negotiating style, the use of empathy, and understanding hypotheses. It remains unclear if this correlation is found during pre- or post-test.

Finally, in the study by Schlundt [16], significant short-term improvements were observed in skills relating to: relationship building, interviewing, problem diagnosis, and behavioural intervention. In four studies, no significant effect of the training on nurses' attitudes, skills, and (or) knowledge was found $[9,14,22,29]$.

\subsubsection{Intention to change}

None of the studies reported nurses' intention to change their behaviour after the training (see Table 2).

\subsubsection{Behavioural changes in nursing practice}

The influence of the training on nurses' behavioural change was measured in the five studies in which video or audio observations were made of nurses with actual patients (see Table 2).

From the study by Booth et al. [19] and Heaven and Maguire [28], it appeared that even after the training, nurses were no better in identifying what cancer patients concerns were. In general, the more disclosure of feeling by the patient, the more blocking behaviours there were from nurses. Booth et al. found a significant small increase of nurses' use of open direct questions. Further, results from Booth's study showed a weak increase in nurses' assessment behaviours after the training. Grond and Visser [9] found that nurses' therapeutic behaviours did not increase after the training.

The only two studies in which significant improvements were measured, were the studies by Kihlgren et al. [20] and Faulkner and Maguire [21]. Kihlgren et al. found that after training, the environment was warmer and friendlier, patients were given more opportunity to make their own choices, the caregivers more often sat and talked to patients, and finally the caregivers showed an increased sensitivity to patients' cues. From the study of Faulkner and Maguire [21], it appeared that after training, nurses increased the use of relevant interviewing techniques and assessment of patients' problems.

\subsubsection{Patient outcomes}

In four studies, patient outcomes were measured (see Table 2). In the study by La Monica et al. [22] and Kihlgren et al. [20], the effect of the training on patients well-being was reported.

La Monica et al. found that patients cared for by trained nurses showed significantly less anxiety and hostility than patients cared for by untrained nurses. Kihlgren et al. found that during the music sessions patients were more active; that there was an increased helpfulness and synchronicity between patients, and that patients were less aggressive.

In the study by Haak and Sylbing [29] and Grond and Visser [9], patients perceptions about the quality of nurses' communicative behaviours were reported.

Haak and Sylbing and Grond and Visser reported that there was no change in patients' perceptions about changes of nurses' communication skills between pre- and post-test. Further Grond and Visser reported that on the whole, patients' perceptions of therapeutic behaviours were positive. 


\section{Discussion}

In this study, an overview is presented of fourteen evaluation studies of communication training programs for nurses. Most of the studies reviewed showed limited effects on nurses' behavioural changes in practice and on patient outcomes. In order to understand those (limited) effects, we reviewed the selected studies on several independent, process, and (mediating) outcome variables as defined by Francke et al. [8].

As regards the independent variables, it is the professional background in particular that is given in most studies. In most programs, psychologists were involved, and in a minority of them nurses. It is not always clear whether there is a relationship between the professional background of the teachers and the effects measured. In his study, Pool [10] suggests that the fact that the trainers were psychologists with limited knowledge about nursing resulted in an approach too general. This could have inhibited effects on nurses' behaviour change in practice. These findings are in line with our findings, that in the only two studies [20,21], in which positive effects on nurses' behavioural changes were found, did the teachers have a nursing background.

It is difficult to find a relationship between characteristics of the program and effects as well. The didactic strategies, a main characteristic of the program itself, varied in relation to positive behavioural changes. Behavioural changes were found in the programs that consisted of theory alone [20] or consisted of only practical exercises [21]. Effects on nurses' skills, knowledge and attitudes were predominantly shown in the studies with the combination of practical and theoretical didactic strategies.

With regard to the communication topics in the training programmes, it is remarkable that no attention is paid to nonverbal communication. In the selected studies, investigators focused exclusively on the verbal component of communication, and neglected the nonverbal component which also influences the interaction between patient and nurse.

In two studies, the importance of the social system in the working environment was mentioned. Pool [10] reported that a negative work environment, which means lack of support from supervisors for use of the newly acquired skills in practice, formed a barrier in putting the skills learned into practice; Booth et al. [19] reported that a positive work environment led to increased use of facilitating behaviours, which means the nurses ability to assess and clarify patients' concerns.

Faulkner and Maguire [21] stressed the importance of giving the participants feedback on their performance in a 'safe environment' with respect to the process variables, as regards the characteristics of the trainer, his/her relationship with the participants, and the relationship between the participants.

As regards the (mediating) outcome variables, the results show that the effects on behavioural changes were limited. Only Kihlgren et al. [20] and Faulkner and Maguire [21] found improved behavioural changes in practice. With regard to skills, knowledge or attitudes, changes were found in four studies [14,16-18].

Although a small number of studies showed some improvement in nurses communicative behaviour in practice, it remains unclear however as to whether these behavioural changes resulted in positive effects on patients as well. Kihlgren et al. [20] and $\mathrm{La}$ Monica et al. [22] assessed patients' well-being. However, the question remains as to whether patients' well-being was affected by more factors than the training alone. It is remarkable that, although $\mathrm{La}$ Monica did not find effects on nurses' communication behaviour, the patients outcomes do give an indication that nurses (and therefore also patients) benefited from the programme which was focused on teaching empathic behaviour. Grond and Visser [9] and Haak and Sylbing [29] could not detect improvements in patients' satisfaction about nurses' communication skills after training. Patients' perceptions were positive and didn't change significantly. Our findings on this accord with other research, which reveals that patient satisfaction is always high, which results in limited variance in the scores [30,31].

With regard to the research methods, we see that an experimental design was used in relatively few studies, which in general is the most reliable design for measuring effectiveness of a training program. It is also worth noting that in the studies using an experimental design $[9,10,14,17,22]$, limited results were reported concerning improved skills $[14,17,18]$ 
and no results are reported concerning behavioural changes [9,22]. According to Black [32] these reduced effects are a consequence of the limitations of experimental trials. In spite of the many advantages of this research design, Black emphasizes that random assignment may interfere with subjects' motivation to participate in the training. This, in turn, may reduce the effects of the training.

In contrast, more effects were reported in the studies with an alternative design [16,19-21]. When considering the studies without a control group however, questions can be raised as to whether the improved skills and behaviours were a result of the training. The pre- and post-test mostly took place immediately before and after the training. However, in the literature it is suggested that the communicative behaviours of the nurses after the training still improve during their nursing practice, which means that it may take some time before the newly acquired or modified behaviours are integrated into the daily routine [33]. Several of the studies reviewed carried out a second follow-up measurement which was generally done three months after the training and in a few studies, at least nine months after the training.

In order to measure nurses' skills and behavioural changes, video and audiotapes were made of nurses with patients. This makes it possible to measure the effect of the training by means of direct observation of nurses' communicative skills and this can therefore be regarded as the most important indicators of training effects. For this purpose, simulated or actual patients participated in the studies. With simulated patients, nurses' competence in their communicative skills can be measured; with real patients nurses' performance of their communicative skills or behavioural change in daily practice can be measured [34]. The advantage of using simulated patients is that they play the same role for every nurse. The disadvantages of working with simulated patients however are that interacting with them may be artificial, and that patient outcomes cannot be measured. A realistic picture can be drawn from working with actual patients, yet actual patients may differ. Uncontrolled patient influences may obscure the measurement of training effect. A combination of working with real as well as with simulated patients could be control for the limits relating to working with one of the two patient groups. This combination was used in none of the selected studies.

Finally, in evaluation studies, the content of the training is standard for every participant. However, participants may differ in their educational needs. In that case, the one participant will learn and benefit more from the training than the other participant. This, in turn can also lead to reduction of the effectiveness of a communication training.

In future studies, more focus should be placed on investigating, evaluating and inculcating skills that optimize nurse-patient communication. From our study it appears that relatively few of these programmes have been evaluated. Evaluation studies are useful in gaining insight into the effect of these programs on nurses' levels of communication skills and other nurse and patient outcomes. Further, an increased focus in research on the evaluation of communication training programs may increase the attention paid to the importance of teaching and evaluating the relevant skills needed to optimize nurse-patient communication. This, in turn, can lead to an enhanced implementation of effective (continuing) education programs for nurses in patient care.

Additionally, future studies should focus more on evaluating nonverbal communication, which has shown to be important with respect to building rapport with patients, and with respect to conveying empathy and support, in nurse-patient interactions. Hitherto the nonverbal component in this area has been widely neglected.

We do not yet possess a complete picture of the influence of the independent, process and outcome variables, as described by Francke et al. [8]. In order to strengthen the theoretical framework of this model, more research is needed to investigate the precise influence of these variables when evaluating the effect of communication training programmes on nurses' communication.

As regards the outcome variables, it is to be recommended that studies should use a combination of real and simulated patients to control for the limits in working with one of the two patient groups.

Finally, the use of experimental research designs can be pursued in future studies in order to eliminate the influence of confounding variables. Although randomization at the individual level is theoretically 
the strongest design, it seems that, especially in field studies, it is practically impossible to keep nurses separate in the control and intervention conditions, especially when they are working on the same ward. Effectiveness of the intervention can be reduced to cross-over of information between the conditions. Randomization at ward level is a suitable alternative, as the groups in both conditions are working on separate wards. In order to investigate the effects of a communication training programme for nurses during interactions with cancer patients, we are currently conducting an experimental pre-test-posttest study, characterized by randomization at ward level.

\section{References}

[1] Wilkinson S. Factors which influence how nurses communicate with cancer patients. J Adv Nurs 1991;16:677-88.

[2] Wilkinson S. Good communication in cancer nursing. Nurs Stand 1992;7(9):35-9.

[3] Bensing JM. Doctor-patient communication and the quality of care. Utrecht: NIVEL, 1991.

[4] Caris-Verhallen WMCM, Kerkstra A, Bensing JM. The role of communication in nursing care for elderly people. A review of the literature. J Adv Nurs 1997;25(5):915-33.

[5] Heintzman M, Leathers DG, Parrott RL, Caims IIIa B. Nonverbal rapport-building behaviours' effect on perceptions of a supervisor. Manag Commun Quart 1993;7(2):181-208.

[6] Peteet JR, Murray-Ross D et al. Job stress satisfaction among the staff members at a cancer center. Cancer 1989;64:97582.

[7] Ross DM, Peteet JR, Medeiros C, Walsh-Burke K, Rieker P. Difference between nurses' and physicians' approach to denial in oncology. Cancer Nurs 1992;15(6):422-8.

[8] Francke AL, Garssen B, Huijer Abu-Saad H. Determinants of changes in nurses' behaviour after continuing education: a literature review. J Adv Nurs 1995;21:371-7.

[9] Grond PJN, Visser APh. Therapeutisch gedrag van verpleegkundigen en het effect van een gesprekstraining. Tvz 1979;32(7):307-14.

[10] Pool JJ. Sociaal-therapeutisch gedrag van verpleegkundigen. Amsterdam: Dissertatie, VU boekhandel/uitgeverij, 1983.

[11] Smith RC, Lyles JS, Mettler J, Stoffelmayr BE, Van Egeren LF et al. The effectiveness of intensive training for residents in interviewing. A randomized, controlled study. Ann Intern Med 1998;128:118-26.

[12] Boink J. The effects of a consultation behaviour training programme for established general practitioners. Amsterdam: Free University, 1996.
[13] Maguire P, Faulkner A, Booth K, Elliot C, Hillier V. Helping cancer patients to disclose their concerns. Eur $\mathrm{J}$ Cancer 1996;32A(1):78-81.

[14] Ravazi D, Delvaux N, Farvacques C, Robaye E. Immediate effectiveness of brief psychological training for health professionals dealing with terminally ill cancer patients. Soc Sci Med 1988;27(4):369-75.

[15] Faulkner A. The evaluation of training programmes for communication skills in palliative care. J Cancer Care 1992;1:75-8.

[16] Schlundt D, Quesenberry L, Pichert JW, Lorenz RA, Boswell EJ. Evaluation of a training program for improving adherence promotion skills. Pat Educ Counsel 1994;24:165-73.

[17] Paxton R, Rhodes D, Crooks I. Teaching nurses therapeutic conversation: a pilot study. J Adv Nurs 1988;13:401-4.

[18] Ravazi D, Delvaux N, Marchhal S, Bredart A, Farvacques C, Paesmans M. The effects of a 24-h psychological training program on attitudes. Communication skills and occupational stress in oncology: a randomised study. Eur $\mathrm{J}$ Cancer 1993;29A(13):1858-63.

[19] Booth K, Maguire PM, Butterworth T, Hillier VF. Perceived professional support and the use of blocking behaviours by hospice nurses. J Adv Nurs 1996;24:522-7.

[20] Kihlgren M, Hallgren A, Norberg A, Bräne G, Karlsson I. Effects of the training of integrity - promoting care on the interaction at a long-term ward. Scand $\mathrm{J}$ Caring Sci 1990;4:21-8.

[21] Faulkner A, Maguire P. Teaching ward nurses to monitor cancer patients. Clin Oncol 1984;10(4):383-9.

[22] La Monica EL, Madea AR, Oberst MT. Empathy and nursing care outcomes. Scholarly Inquir for Nurs Pract 1987;I:197-213.

[23] Neuteboom P. Opleiding in gespreksvoering, beschrijving en effectonderzoek. Meinema N.V. Delft: Proefschrift, 1966.

[24] Truax RR, Carkhuff CB. Towards effective counseling and psychotherapy. Chicago: Aldine Press, 1967.

[25] Cassee ETh. In: Cassee ETh, Lammers CJ, editors, Kommunicatie en therapeutisch gedrag, 1973, pp. 73-81.

[26] Jonkers L. De persoonlijke roldiscrepantie tussen rolopvatting en het rolgedrag van leerlingverpleegkundigen. Amsterdam: Vrije Universiteit, doctoraalscriptie Sociale Psychologie, 1974.

[27] Poortinga A. De invloed van stratificatie op de verpleegafdeling. Amsterdam: Vrije Universiteit, doctoraalscriptie Sociale Psychologie, 1975.

[28] Heaven CM, Maguire P. Training hospice nurses to elicit patient concerns. J Adv Nurs 1996;23:280-6.

[29] Haak TW, Sijlbing R. Gesprekstraining aan verpleegkundigen. Gezondheid and Samenleving 1982;3(3):160-4.

[30] Frederikson LG. Exploring information exchange in consultations: patients' view of performance and outcomes. Pat Educ Counsel 1995;25:237-46.

[31] Cohen G. Age and health status in a patient satisfaction survey. Soc Sci Med 1996;42:1085-93.

[32] Black N. Why we need observational studies to evaluate the effectiveness of health care. Br Med J 1996;312:1215-8. 
[33] Hulsman RL. Communication skills of medical specialists in oncology. Development and evaluation of a computer assisted instruction program. Dissertation, University Utrecht, 1998.

[34] Pieters HM. De Utrechtse Consult Evaluatie Methode:
Vaardigheden in consultvoering van huisartsen in opleiding getoetst (The Utrecht Consultation Assessment Method: The assessment of consultation skills of trainees in the vocational training). Dissertation, University Utrecht, MEDITekst, Lelystad, 1991. 